\title{
CELL THERAPY IN THE TREATMENT OF INTERVERTEBRAL DISC DEGENERATION
}

\author{
TERAPIA CELULAR NO TRATAMENTO DA DEGENERAÇÃO DE DISCO INTERVERTEBRAL
}

\author{
TERAPIA CELULAR EN EL TRATAMIENTO DE LA DEGENERACIÓN DE DISCO \\ INTERVERTEBRAL

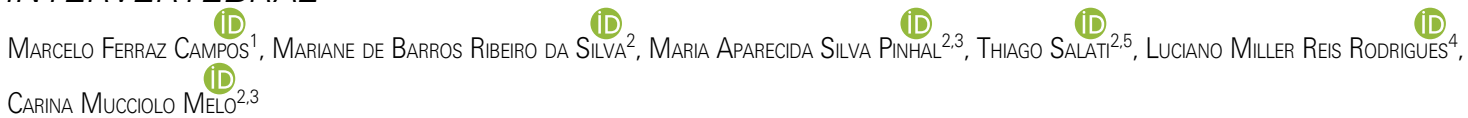

1. Complexo Hospitalar Heliópolis, Department of Neurosurgery, São Paulo, SP Brazil.

2. Universidade Federal de São Paulo (UNIFESP), Department of Biochemistry, São Paulo, SP, Brazil.

3. Faculdade de Medicina do ABC (FMABC), Department of Biochemistry, Santo André, SP, Brazil.

4. Faculdade de Medicina do ABC (FMABC), Department of Orthopedics, Santo André, SP, Brazil.

5. Universidade Federal de São Paulo, Program in Neurosurgery, São Paulo, SP, Brazil.

\begin{abstract}
Approximately $80 \%$ of the world population experiences some type of back pain at some point in their life, and in $10 \%$ of this population the pain causes chronic disability resulting in a high cost for the treatment of these patients, in addition to compromising their work and social interaction abilities. Current treatment strategies include the surgical procedure for degenerated intervertebral disc resection, the nerve root block and physiotherapy. However, such treatments only relieve symptoms and do not prevent the degeneration of intervertebral discs. Therefore, new therapeutic strategies have emerged and include manipulating cells to recover the degenerated disc. This article will discuss the possible cell therapy alternatives used in the disc regeneration process, featuring a descriptive study of translational medicine that involves clinical aspects of new treatment alternatives and knowledge of basic research areas, such as cellular and molecular biology. Level of evidence V; Expert Opinion.
\end{abstract}

Keywords: Intervertebral Disc; Cell Therapy; Tridimensional Cell Culture.

\section{RESUMO}

Aproximadamente $80 \%$ da população mundial sofre algum tipo de dor nas costas em alguma fase de vida, sendo que em $10 \%$ dessa população, as dores acarretam incapacidade crônica, deflagrando alto custo de tratamento desses pacientes, além de comprometer as habilidades de trabalho e convívio social desses indivíduos. As estratégias de tratamento atuais incluem o procedimento cirúrgico por ressecção do disco intervertebral degenerado, bloqueio de raízes nervosas e fisioterapia. Entretanto, tais tratamentos apenas aliviam os sintomas e não impedem que ocorra a degeneração de discos intervertebrais. Portanto, novas estratégias terapêuticas têm surgido e incluem a manipulação de células com o objetivo de recuperar o disco degenerado. No presente artigo, serão discutidas as diferentes possibilidades alternativas de terapias celulares no processo de regeneração discal, caracterizando um estudo descritivo da medicina translacional que envolve aspectos clínicos de novas alternativas de tratamento e o conhecimento de áreas básicas de pesquisa como biologia celular e molecular. Nível de evidência V; Opinião do Especialista.

Descritores: Disco Intervertebral; Terapia Celular; Cultura Celular Tridimensional.

\section{RESUMEN}

Aproximadamente $80 \%$ de la población mundial sufre algún tipo de dolor de espalda en alguna etapa de la vida, y en $10 \%$ de esa población, los dolores causan incapacidad crónica, deflagrando alto costo de tratamiento de esos pacientes, además de comprometer las habilidades laborales y convivencia social de esos individuos. Las estrategias de tratamiento actuales incluyen el procedimiento quirúrgico para la resección del disco intervertebral degenerado, bloqueo de las raíces nerviosas y fisioterapia. Entretanto, tales tratamientos solo alivian los síntomas y no impiden que ocurra la degeneración de discos intervertebrales. Por lo tanto, han surgido nuevas estrategias terapéuticas e incluyen la manipulación de células con el objetivo de recuperar el disco degenerado. En el presente artículo se discutirán las diferentes posibilidades alternativas de las terapias celulares en el proceso de regeneración discal, caracterizando un estudio descriptivo de la medicina traslacional que involucra aspectos clínicos de nuevas alternativas de tratamiento y conocimiento de áreas básicas de investigación como biología celular y molecular. Nivel de evidencia V; Opinión del especialista.

Descriptores: Disco Intervertebral; Terapia Celular; Cultura Celular Tridimensional.

Study conducted at the UNIFESP - Universidade Federal de São Paulo, Department of Biochemistry, Program in Molecular Biology, São Paulo, SP, Brazil.

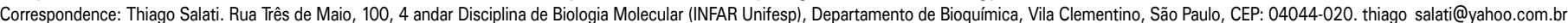




\section{INTRODUCTION}

The intervertebral disc consists of a central gelatinous region called the nucleus pulposus (NP), an outer fibrous tissue ring called the annulus fibrosus (AF) that surrounds the NP, and two hyaline cartilage endplates that cover the upper and lower surfaces of the $\mathrm{AF}$ and the NP and act as the interface between the intervertebral disc and the vertebra. ${ }^{1}$

The endplates separate the NP and the AF from the center of the vertebral body and permit fixation of the AF fibers to the bone structures. They are also responsible for the nutrition of the intervertebral disc, which is accomplished via the diffusion of oxygen and nutrients from the bone marrow spaces of the vertebral body. ${ }^{1,2}$

Although only $1 \%$ of intervertebral disc volume is cellular, its role is vital, as it is responsible for the composition and turnover of the tissue. The disc has at least three distinct cellular populations: chondrocyte-like cells in the NP, fibrocartilaginous cells in the internal $A F$, and fibroblasts in the external $A^{3}{ }^{3}$

The cells of the intervertebral disc can also be stimulated by several factors, including mechanical stress, the supplying of nutrients and osmotic and ionic environments. The cells depend on the capillaries located in the margins of the AF and on blood flow under the hyaline cartilage of the endplate to supply nutrients and remove metabolic products. ${ }^{4}$

In recent years, new therapeutic strategies for intervertebral disc regeneration have emerged involving the use of growth factors and cellular therapies. In vitro tests have made great advances in knowledge possible in the area of new strategies for the process of intervertebral disc regeneration.

The shape of the cell also seems to influence what type of extracellular matrix component is synthesized. Intervertebral disc cells can be considered a variety of chondrocyte modulated by the organization of its cytoskeleton to produce the macromolecules found in the extracellular matrix of the intervertebral disc. ${ }^{5,6}$

The extracellular matrix of the intervertebral disc is produced and maintained by cells and composed essentially of collagen, proteoglycans, glycoproteins, glycosidases and proteases. Significant changes in components of the extracellular matrix have been shown to occur during the process of intervertebral disc degeneration, as well as in diseases involving disc herniation. ${ }^{7-9}$

One of the primary functions of the constituent cells of the intervertebral disc is to produce extracellular matrix (ECM). Reconstitution of the ECM components in degenerated intervertebral discs is one of the strategies behind therapies that involve tissue regeneration. This result can be achieved through cellular therapies that use cells that produce extracellular matrix components or through the use of stem cells that can undergo differentiation in situ and then generate ECM.

Cellular therapy in conjunction with the use of biomolecules such as TGF- $\beta$ (transforming growth factor), BMP (bone morphogenetic proteins), PDGF (platelet-derived growth factor), IGF (insulin-like growth factor), and VEGF (vascular endothelial growth factor) among others induce cellular proliferation and production of ECM components.

\section{Cell types with degenerated intervertebral disc therapy potential}

We will present possibilities of using different cell types as an alternative for treatment of intervertebral disc degeneration.

We know that stem cells are characterized by remarkable plasticity and the ability to differentiate themselves into other types of cell. Stem cells can originate from bone marrow (BMSCs, bone marrow-derived mesenchymal stem cells), from adipose tissue (ADSCs), from joint tissue (SMSCs, synovium-derived mesenchymal stem cells), from the umbilical cord (UCMSCs), as well as from other tissues and organs.

Stem cells secrete biologically active factors with immunomodulatory and angiogenic properties and inhibit leukocyte activity, which actively participates in inflammatory processes, and which justifies the use of stem cells in the treatment and repair of damaged myocardium, in the first stage of shock, and transplantation of stem cells to the nucleus pulposus of the intervertebral disc, knee and hip joint in progressive inflammatory lesions, creating new opportunities for patients who are permanently disabled. ${ }^{10}$

Cellular therapies with stem cells have been widely used in cases of osteoarthritis and joint cartilage repair. ${ }^{11-13}$

Stem cells are usually referred to as pluripotent cells, derive from three germlines (endoderm, ectoderm and mesoderm) and have the ability to originate any cellular type depending on the microenvironment.

Mesenchymal stem cells (MSC) are multipotent cells derived from the mesoderm and can differentiate into various cell types. One of their main characteristics is that they are not immunogenic.

Embryonic stem cells (ES) are pluripotent and derived from the initial stages of embryonic development, but the development of tumors is still one of the greatest barriers to the use of embryonic stem cells. ${ }^{14}$

To date, the use of stem cells as therapy for the intervertebral disc degeneration process has been proven to be safe, although the results of such therapy in the long term have not been fully elucidated. Clinical trials that use cellular therapy may show advantages when compared to the aggressive treatment of surgical interventions.

It has been shown that changes in the phenotype of the intervertebral disc cells correlate with the degree of disc degeneration. Additionally, notochordal cells present in the NP (nucleus pulposus) of intervertebral discs synthesize proteoglycans, which exhibit less aggregation as compared to proteoglycans synthesized by nucleus pulposus cells. Such observations have shown that the composition of the type of cells of the nucleus pulposus produce a distinct extracellular matrix that can affect tissue integrity. ${ }^{15}$

Figure 1 identifies the cell types that could potentially be used as a source for the treatment of degenerated intervertebral discs.

The presence and location of cells that express notochordal cell markers in the intervertebral lumbar discs of humans of all ages and varying levels of disc degeneration has been investigated and the results indicate that the cells, analyzed immunohistochemically, that have a phenotype similar to that of notochords are present in a considerable portion of the intervertebral lumbar discs of adults. The presence of these cells is associated with distinct early disc degeneration characteristics, in particular with changes in the granular matrix. ${ }^{16}$

We should consider that autologous intervertebral disc cell transplantation is a new approach that is extremely safe and technically more appropriate.

However, one of the disadvantages of using autologous cells is that it requires the ex vivo expansion of the cells, which entails additional cost, time, and standardized protocols that go beyond the surgical procedure and medical care, necessitating an interface between professionals from the general experimental area and physicians.

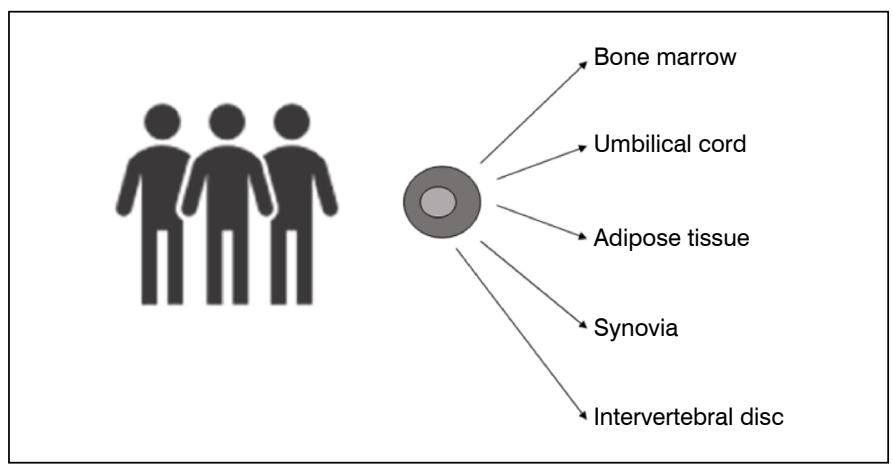

Figure 1. Types of cells that can be used in cellular therapy. Stem cells originated from the bone marrow (BMSC, bone marrow-derived mesenchymal stem cells), stem cells obtained from adipose tissue (ADSC, adipose stem cells), stem cells from joint tissue (SMSC, synovium-derived mesenchymal stem cells), and cells from the umbilical cord (UCMSC, umbilical cord-derived mesenchymal stem cells). 
The cells obtained for intervertebral disc treatment can originate from two-dimensional cultures (2D cultures), where the cells are cultivated in polystyrene plates or flask and grow in monolayers. However, the 2D system has some disadvantages when compared to cells cultivated in three dimensions (3D cultures). 3D cellular cultures preserve the phenotype and are surrounded by an extracellular matrix. Cells in 3D cultures can be cultivated in culture media containing agarose, collagen, hyaluronic acid or synthetic materials, such as polylactic acid and polyethylene glycol.

Autologous chondrocyte transplantation is one of the cellular therapy techniques used, since these cells effectively participate in the formation of the extracellular matrix of the intervertebral disc and, thus, contribute to the process of intervertebral disc regeneration. However, there are limitations in this type of therapy, which involve the need to expand the chondrocytes in culture because they are slow to proliferate in vitro and they require the removal of biopsies from the intervertebral disc adjacent to the degenerated intervertebral disc, which can injure the tissue and contribute to the disc degeneration process.

On a more complex level, we can mention cell cultures that mimic organs and tissues. For example, co-culture can be performed between NP and AF cells in combination with mesenchymal stem cells. Additionally, organoid culture can be achieved by culturing tissue obtained from the intervertebral disc using a bioreactor system that mimics mechanical conditions. ${ }^{17-19}$

In view of these considerations, the use of mesenchymal stem cells (MSC) collected from bone marrow has proved to be a more favorable alternative than chondrocyte transplantation, since MSCs are pluripotent cells with a high capacity for rapid proliferation, as well as the ability to produce cytokines, such as interleukins, that are known to assist in the disc regeneration process. MSCs can differentiate into chondrocytes and NP cells as long as the microenvironment is favorable to such differentiation, which includes a favorable $\mathrm{pH}$ and specific factors. MSCs have been shown to be capable of undergoing differentiation into NPs in the presence of hypoxia and TGF- $\beta$. Alternatively, the use of 3D cultures obtained from MSCs has been another therapeutic alternative, and the great advantage of obtaining 3D cultures is the formation of cultures that exhibit greater proliferation and extracellular matrix production, including the synthesis of proteoglycans.

In addition to the use of cellular therapy for tissue regeneration, as for example in degenerative intervertebral disc disease, three-dimensional cell cultures (3D cultures) are also potentially applicable to the investigation of molecular processes in various diseases, to the development of new drugs and to personalized medicine aimed at testing medications in cell cultures specific to the patient, as shown in Figure 2.

The results shown in $x x x x$ indicate that the use of three-dimensional cultures of tissues obtained by surgical resection of degenerated intervertebral discs is quite a promising therapeutic alternative for intervertebral discs adjacent to the surgery, as in some cases these discs also present some degree of degeneration. One advantage of this method is that the cells are obtained from the patient's own tissue that would be discarded and these cells have high potential for differentiation into chondrocytes, as well as a high capacity for extracellular matrix production.

Three-dimensional degenerated intervertebral disc cultures can be obtained within a period of two to three weeks using tissue collected by surgical resection, which represents a reasonable period of time before the patient is submitted to a new procedure to inoculate the cells into the discs adjacent to the prosthesis, suggesting a favorable treatment alternative for patients affected by disc degeneration.

All authors declare no potential conflict of interest related to this article.

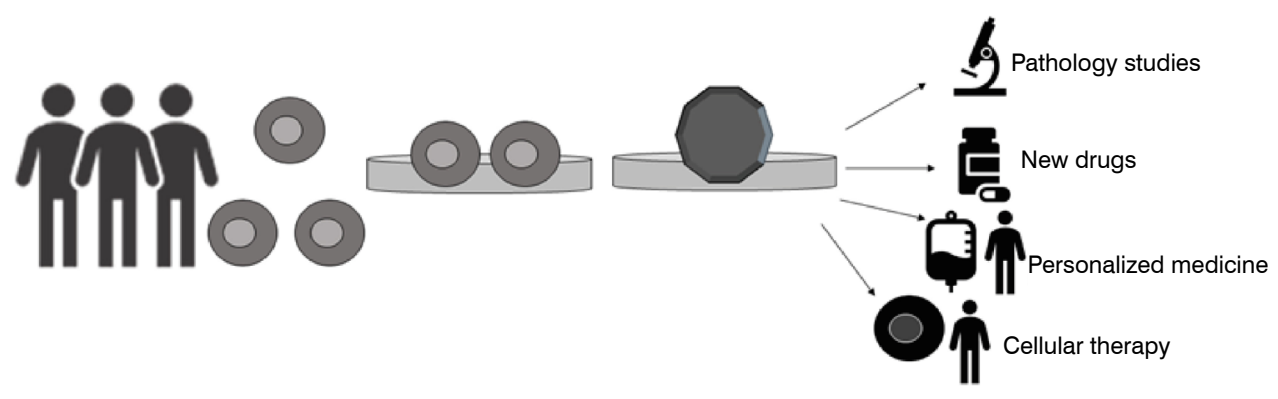

Figure 2. Application of three-dimensional cell cultures (3D cultures). Investigation of the molecular mechanisms of various disease, development of new drugs, investigation of medications effective in personalized medicine and cell therapies for tissue regeneration.

CONTRIBUTION OF THE AUTHORS: MFC, TS and LMRR are assistants who performed surgeries, monitored patients and gathered the clinical data for this manuscript. MASP and CMM contributed with the intellectual concept of the basic research and experimental aspects of the study. MBRS created and reviewed the bibliography. All authors contributed to the writing of the manuscript and review of the final version.

\section{REFERENCES}

1. Smith LJ, Nerukar NL, Choi KS, Harfe BD, Elliott DM. Degeneration and regeneration of the intervertebral disc: lessons from development. Dis Model Mech. 2011:4(1):31-41. doi: $10.1242 / \mathrm{dmm} .006403$.

2. Urban JP; Roberts S. Degeneration of the intervertebral disc. Arthritis Res Ther. 2003:5(3):120-30. doi: 10.1186/ar629

3. Martínez EG, García-Cosamalón J, Gan-Cosamaçón I, Blanco ME, Suarez-García O, Veja JÁ. [Biology and mechanobiology of the intervertebral disc]. Neurocirugia (Astur). 2017;28(3):135-40. doi: 10.1016/j.neucir.2016.12.002.

4. Hee HT, Chuah YJ, Tan BHM, Setiobudi T, Wong HK. Vascularization and morphological changes of the endplate after axial compression and distraction of the intervertebral disc. Spine (Phila Pa 1976). 2011;36(7):5050-11. doi: 10.1097/BRS.0b013e3181d32410.

5. Bruehlmann SB, Rattner JB, Matyas JR, Duncan NA. Regional variations in the cellular matrix of the annulus fibrosus of the intervertebral disc. J Anat. 2002;201(2):159-71. doi: 10.1046/j.1469-7580.2002.00080.x

6. Horner HA, Roberts S, Bielby RC, Menage J, Evans H, Urban JPG. Cells from different regions of the intervertebral disc: effect of culture system on matrix expression and cell phenotype. Spine (Phila Pa 1976). 2002;27(10):1018-28. doi: 10.1097/00007632-20020515000004. 
7. Campos MF, Oliveira CP, Pinhal MAS, Rodrigues LMR. Expressão das Metaloproteases 2 E 9 da matriz e TGF- $\beta$ na hipertrifia do ligamento amarelo. Coluna/Columna. 2014;13(3):206-9. doi:10.1590/S1808-18512014130300451.

8. Oliveira CP, Rodrigues LMR, Fregni MVVD, Gotfryd A, Mader AM, Pinhal MAS. Extracellula matrix remodeling in intervertebral disc degeneration. Acta Ortop Bras. 2013;21(3):144-9. doi:10.1590/S1413-78522013000300003

9. Rodrigues LMR, Theodoro TR, Matos LL, Mader AM, Milani C, Pinhal MAS. Heparanase isoform expression and extracellular matrix remodeling in intervertebral disc degenerative disease. Clinics. 2011;66(5):903-9. doi:10.1590/S1807-59322011000500030.

10. Płusa T, Baranowska A, Baranowski P. [Stem cells in contemporary medicine]. Po Merkur Lekarski. 2019;46(271):5-8.

11. Freitag J, Bates D, Boyd R, Shah K, Barnard A, Huguenin L, et al. Mesenchymal stem cell therapy in the treatment of osteoarthritis: reparative pathways, safety and efficacy - a review. BMC Musculoskelet Disord. 2016;17:230. doi: 10.1186/s12891-016-1085-9.

12. McGonagle D, Baboolal TG, Jones E. Native joint-resident mesenchymal stem cells for cartilage repair in osteoarthritis. Nat Rev Rheumatol. 2017;13(12):719-30. doi: 10.1038/ nrrheum.2017.182.

13. Pattappa G, Zellner J, Johnstone B, Docheva D, Angele P. Cells under pressure - the relationship between hydrostatic pressure and mesenchymal stem cell chondrogenesis. Eur Cell Mater. 2019;37:360-81. doi: 10.22203/eCM.v037a22.

14. Gutierrez-Aranda I, Ramos-Mejia V, Bueno C, Munoz-Lopez M, Real PJ, Mácia A, et al. Human induced pluripotent stem cells develop teratoma more efficiently and faster than human embryonic stem cells regardless the site of injection. Stem Cells. 2010;28(9):156870. doi: 10.1002/stem.471

15. Cappello R, Bird JLE, Pfeiffer D, Bayliss MT, Dudhia J. Notochordal cell produce and assemble extracellular matrix in a distinct manner, which may be responsible for the maintenance of healthy nucleus pulposus. Spine (Phila Pa 1976). 2006;31(8):873-82. doi: 10.1097/01. brs.0000209302.00820.fd.

16. Weiler C, Nerlich AG, Bachmeier BE, Boos N. Expression and distribution of tumor necrosis factor alpha in human lumbar intervertebral discs: a study in surgical specimen and autopsy controls. Spine (Phila Pa 1976). 2005;30(1):44-53; discussion 54. doi: 10.1097/01. brs.0000149186.63457.20

17. Ponnappan RK, Markova DZ, Antonio PJD, Murray HB, Vaccaro AR, Shapiro IV, et al. An organ culture system to model early degenerative changes of the intervertebral disc. Arthritis Res Ther. 2011;13(5):R171. doi: 10.1186/ar3494.

18. Chan SCW, Walser J, Kappeli P, Shamsollahi MJ, Ferguson SJ, Gantenbeis-Ritter B. Region specific response of intervertebral disc cells to complex dynamic loading: an organ culture study using a dynamic torsion-compression bioreactor. PLoS One. 2013:8(8):e72489. doi: 10.1371/journal.pone.0072489.

19. Walter BA, Illien-Junger S, Nasser PR, Hecht AC, latridis JC. Development and validation of a bioreactor system for dynamic loading and mechanical characterization of whole human intervertebral discs in organ culture. J Biomech. 2014;47(9):2095-101. doi: 10.1016/j. jbiomech.2014.03.015 